\title{
PENGARUH KOMPETENSI, PROFESIONALISME, DAN PENGALAMAN KERJA AUDITOR TERHADAP KUALITAS AUDIT INTERNAL PADA PERUSAHAAN SWASTA DAN BUMN DI PADANG
}

\author{
Ragil Gusfiardi ${ }^{1}$, Charoline Cheisvyanny ${ }^{2}$, Vita Fitria Sari ${ }^{3}$ \\ ${ }^{1}$ Alumni Jurusan Akuntansi Fakultas Ekonomi, Universitas Negeri Padang \\ ${ }^{2}$ Jurusan Akuntansi Fakultas Ekonomi, Universitas Negeri Padang \\ ${ }^{3}$ Jurusan Akuntansi Fakultas Ekonomi, Universitas Negeri Padang \\ *Korespondensi: ragil.gusfiardi@gmail.com
}

\begin{abstract}
This study aims to determine the effect of Influence of competence, professionalism, and work experience on the quality of internal audit in private and state-owned companies in the city of Padang. The population in this study are private companies and state-owned companies in the city of Padang, which have several internal auditors in their company. The sample in this study were all internal auditors in private companies and BUMN in the city of Padang. Data source is primary data. Data collection techniques with a questionnaire. The data analysis technique is multiple linear regression. The results showed that: (1) Competence had no significant effect on the quality of internal audit, where the tcount of $1.514<2,042$ ttable at sig $0.140>\alpha 0.05$ which meant $H 1$ was rejected, (2) Professionalism had no significant effect on the quality of internal audit, where the value tcount 1,300 <2,042 ttable at sig 0,204> $\alpha$ 0,05 which means $H 2$ is rejected, and (3) Work Experience has a significant positive effect on

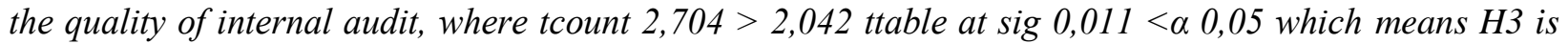
accepted.
\end{abstract}

Keywords: Internal Audit Quality, Competence, Professionalism, and Work Experience

How to cite (APA $6^{\text {th }}$ style)

Gusfiardi, R, Cheisvyanny, C. \& Sari, V. F. (2019). Pengaruh Kompetensi, Profesionalisme, dan Pengalaman Kerja Auditor terhadap Kualitas Audit Internal pada Perusahaan Swasta dan BUMN di Padang. Jurnal Eksplorasi Akuntansi, 1(4), Seri B, 1828-1844.

\section{PENDAHULUAN}

Laporan keuangan merupakan bentuk pertanggung jawaban manajemen atas sumberdaya yang dipercayakan kepadanya. Oleh karena itu, laporan keuangan perlu diaudit oleh pihak ketiga yang independen, yaitu auditor independen untuk meningkatkan kepercayaan para penggunanya (SFAC No. 1). Kepercayaan yang besar dari pemakai laporan keuangan yang diberikan kepada auditor, mengharuskan auditor memperhatikan kualitas auditnya. Untuk meningkatkan efesiensi dan efektivitas dari kegiatan usahanya, suatu perusahaan sangat memerlukan adanya departemen audit internal (Vince, 2017).

Menurut Sawyer (2009:10), pengertian audit internal adalah sebuah penelitian yang sistematis dan objektif yang dilakukan auditor internal terhadap operasi dan kontrol yang berbeda-beda dalam organisasi untuk menentukan apakah: (a) informasi keuangan dan operasi 
telah akurat dan dapat diandalkan, (b) risiko yang dihadapi perusahaan telah diidentifikasikan dan diminimalisasi, (c) peraturan eksternal serta kebijakan dan prosedur internal yang bisa diterima telah diikuti, (d) kriteria operasi yang memuaskan telah dipenuhi, (e) sumber daya yang telah digunakan secara efesien dan ekonomis, dan (f) tujuan organisasi telah dicapai secara efektif. Semua itu dilakukan dengan tujuan untuk dikonsultasikan dengan manajemen dan membantu anggota organisasi dalam menjelaskan tanggung jawabnya secara efektif.

Maraknya kasus kecurangan yang terjadi didalam perusahaan mengakibatkan kebutuhan akan audit internal semakin meningkat. Semakin banyak perusahaan yang menggunakan audit internal karena audit internal dianggap sebagai tolak ukur suatu perusahaan untuk menjelaskan kondisi perusahaan tersebut. Audit internal memberikan peranan yang besar bagi pihak manajemen perusahaan dalam pengambilan keputusan. Selain itu auditor internal diharapkan dapat lebih memberikan sumbangan bagi perbaikan efisiensi dan efektivitas dalam rangka peningkatan kinerja organisasi (Robi, 2015).

Auditor eksternal dalam melakukan tugasnya akan melihat bagaimana kualitas audit internal dalam perusahaan sebagai suatu indikator pengendalian terhadap segala kecurangankecurangan dan kesalahan-kesalahan yang rentan dilakukan oleh manajemen perusahaan (Rosnidah, 2012). Jika auditor menilai bahwa kualitas audit internal kurang baik, maka hal tersebut mengindikasikan bahwa fungsi pengendalian internal dalam perusahaan tersebut juga rendah, sehingga keperacayaan auditor eksternal terhadap auditor internal sangat tergantung dari hasil penilaian kualitas audit internal dalam suatu perusahaan, dengan demikian, kualitas audit internal merupakan hal yang penting bagi perusahaan untuk meningkatkan kepercayaan auditor eksternal selaku pihak independen yang berada di luar perusahaan maupun pihak-pihak yang berkepentingan terhadap perusahaan.

Salah satu kasus terkait mengenai kualitas audit internal terjadi di salah satu perusahaan yaitu perusahaan Toshiba. Pada saat tengah terjadi krisis global tahun 2008 krisis tersebut juga melanda usaha Toshiba hingga akhirnya Toshiba melakukan suatu kebohongan melalui accounting fraud senilai 1.22 milyar dolar Amerika. Tindakan ini dilakukan dengan berbagai upaya sehingga menghasilkan laba yang tidak sesuai dengan realita. Berdasarkan informasi tersebut diketahui bahwa manajemen perusahaan menetapkan target laba yang tidak realistis sehingga saat target tersebut tidak tercapai, pemimpin divisi terpaksa harus berbohong dengan memanipulasi datalaporan keuangan. Selain itu hasil investigasi juga menunjukkan masalah internal sehingga Toshiba gagal untuk mencegah tanda-tanda yang merugikan perusahaan. Hal tersebut masih menjadi indikasi bahwa pelaksanaan audit internal pada perusahaan Toshiba tidak berjalan dengan optimal, sedangkan hal ini merupakan tugas dari pengawas intern yang seharusnya mampu melaksanakan audit internal yang berkualitas bagi perusahaan.

Salah satu faktor yang mempengaruhi kualitas audit internal adalah Kompetensi (Putri, 2015; Ajeng, 2016 ; Christiawan, 2002). Kompetensi adalah pengetahuan dan kemampuan yang harus dimiliki oleh seorang auditor untuk bisa melaksanakan audit dengan benar. Dalam melaksanakan tugasnya,auditor internal harus memiliki pengetahuan yang memadai dan keahlian khusus dibidangnya, kompetensi auditor sangat penting bagi perusahaan agar dapat menghasilkan kualitas audit internal yang baik. Semakin berkompeten seorang auditor maka semakin baik kinerja yang dihasilkan oleh auditor yang juga dapat meningkatkan kualitas audit internal. Kompetensi dapat menetukan keberhasilan dalam pelaksanaan audit, tanpa kompetensi auditor internal pelaksanaan audit internal kurang berkualitas. Kualias audit dapat dicapai jika auditor memiliki kompetensi yang baik (Purwati, 2007). 
Faktor lain yang mempengaruhi kualitas audit internal adalah Profesionalisme (Putri, 2015; Antonius 2011 ; Arens dan Loebbecke 2008). Profesionalisme dapat diartikan sikap dan prilaku auditor dalam menjalakankan profesinya dengan kesungguhan dan tanggung jawab, serta memelihara citra publik. Martak (2015) menyatakan bahwa profesionalisme merupakan mutu, kualitas, atau prilaku yang menunjukan profesi seseorang atau orang yang profesional. Profesionalisme seorang auditor merupakan syarat utama bagi profesi tersebut, karena dengan memiliki pandangan profesionalisme yang tinggi maka para pihak yang akan mengambil keputusan akan percaya terhadap hasil audit mereka. Auditor internal dituntut secara profesional untuk melaksanakan fungsi audit dengan baik. Jadi seorang auditor dapat menghasilkan laporan audit yang berkualitas jika auditor tersebut melaksanakan pekerjaanya secara profesional.

Selanjutnya faktor yang diduga mempengaruhi kualitas audit internal adalah pengalaman kerja (Ahmad, 2016 ; Diah 2014, Ajeng 2016). Pengalaman kerja adalah kemampuan atau keterampilan dari lamanya bekerja. Dilihat dari segi lamanya menjadi auditor, seorang auditor yang kurang berpengalaman akan lebih banyak melakukan kesalahan dalam melakukan pekerjaan dibandingkan dengan dengan auditor yang sudah berpengalaman, yang mana membuat auditor tersebut memiliki kemampuan untuk memperoleh informasi yang relevan, mendeteksi kesalahan, dan mencari penyebab munculnya masalah. Hal ini menjadikan bahwa semakin lama masa kerja dan pengalaman auditor maka akan semakin baik dan meningkatnya kualitas audit yang dihasilkan.

Beberapa penelitian terdahulu mengenai faktor-faktor yang serupa dengan peneliti terkait kualitas audit internal diantaranya adalah Ajeng (2016) yang meneliti variabel pengalaman kerja, kompetensi, dan independensi pada inspektorat provinsi daerah Istimewa Yogyakarta. Hasil penelitiannya adalah bahwa pengalaman kerja, kompetensi dan independensi berpengaruh terhadap kualitas audit internal. Putri (2015) meneliti pengaruh kompetensi dan profesionalisme auditor internal terhadap kualitas audit pada BUMN dan BUMD di Yogyakarta. Hasil penelitian menunjuk bahwa kompetensi auditor, profesional auditor berpengaruh positif dan signifikan terhadap kualitas audit. Peneltian Samsi dkk (2013) yang meneliti variabel pengalaman kerja, independensi, dan kompetensi pada inspektorat provinsi daerah Istimewa Yogyakarta. Hasil penelitiannya menunjukan bahwa variabel pengalaman kerja berpengaruh negatif terhadap kualitas audit, independensi berpengaruh positif terhadap kualitas audit, sedangkan kompetensi tidak berpengaruh terhadap kualitas audit.

Penelitan kualitas audit internal masih penting untuk dilakukan. Hal ini dikarenakan auditor internal sebagai bagian dalam organisasi bertugas untuk mengaudit laporan keuangan, memberikan saran dan rekomendasi yang dibutuhkan untuk nantinya dapat digunakan sebagai dasar pengambilan keputusan. Meskipun penelitian ini mengacu pada penelitian sebelumnya akan tetapi terdapat perbedaan objek dan lokasi penelitian, dimana objek penelitian ini dilakukan pada Perusahaan Swasta dan BUMN yang ada di Kota Padang dengan melihat apakah ke tiga variabel tersebut berpengaruh terhadap kualitas audit internal.

Berdasarkan uraian pada latar belakang diatas, serta perbedaan hasil yang diperoleh dari beberapa penelitian terdahulu, maka peneliti tertarik untuk melakukan penelitian dengan judul. "Pengaruh Kompetensi, Profesionalisme, dan Pengalaman Kerja Auditor terhadap Kualitas Audit Internal pada Perusahaan Swasta dan BUMN Di Padang” 


\section{REVIU LITERATUR DAN HIPOTESIS \\ Teori Atribusi}

Teori atribusi merupakan teori yang dicetuskan oleh Fritz Heider yang menjelaskan tentang perilaku seseorang. Teori ini menjelaskan mengenai suatu proses bagaimana seseorang menentukan penyebab dan motif tentang perilaku seseorang lainnya. Teori atribusi ini mengacu mengenai bagaimana seseorang dapat menjelaskan penyebab perilaku dari orang lain ataupun diri mereka sendiri yang dapat ditentukan dari sisi internal mereka, seperti sifat, karakter, sikap, ataupun dari sisi eksternal mereka seperti tekanan situasi atau keadaan tertentu yang akan memberikan pengaruh terhadap perilaku individu (Ayuningtyas, 2012).

\section{Kualitas Audit}

Menurut De Anglo (1981) dalam Restu dan Nastia (2013) menyatakan kualitas audit adalah bagaimana seorang auditor akan menemukan lalu melaporkan penyimpangan yang ditemui saat pemeriksaan. Ikatan Akuntan Indonesia (IA) menyatakan bahwa audit yang dilakukan oleh auditor dikatakan berkualitas apabila memenuhi standar auditing dan standar pengendalian mutu.

Dari beberapa pengertian mengenai kualitas audit diatas, dapat diambil kesimpulan bahwa kualitas audit internal merupakan tindakan dimana seorang auditor melaporkan hasil auditnya berdasarkan bukti-bukti yang ada kepada pihak yang berkepentingan sesuai dengan standar auditing yang sudah ditetapkan. Menurut konsorsium organisasi profesi audit internal, indikator pengukuran kualitas audit antara lain :

a. Pengelolaan fungsi audit internal

b. Lingkup Penugasan

c. Perencanaan Penugasan

d. Pelaksanaan Penugasan

e. Komunikasi Hasil Penugasan

f. Pemantaun Tindak Lanjut

\section{Kompetensi}

Kompetensi auditor adalah kualifikasi yang dibutuhkan oleh auditor untuk melaksanakan audit dengan benar (Antonius, 2015). Dalam melaksanakan audit, seorang auditor harus memiliki mutu profesional yang baik, pengetahuan yang memadai, serta keahlian khusus dibidangnya. Menurut Sawyer et al (2005) kompetensi auditor internal dapat diartikan sebagai sebuah hubungan cara-cara setiap auditor internal memanfaatkan pengetahuan, keahlian, dan prilakunya dalam bekerja.

Dari beberapa pengertian mengenai kompetensi auditor internal diatas, dapat disimpulkan bahwa kompetensi yaitu suatu kemampuan yang dimiliki seorang auditor untuk dapat melaksanakan atau melakukan suatu pekerjaan berdasarkan atas keterampilan dan pengetahuan,serta adanya pengalaman yang akan membentuk kompetensi tersebut dengan sendirinya dari lamanya auditor internal tersebut melakukan proses audit.

\section{Indikator Pengukuran Variabel Kompetensi Auditor}

Indikator Pengukuran Standar Kompetensi Auditor (Putri, 2015) antara lain pengetahuan, keterampilan, sikap Prilaku 


\section{Profesionalisme}

Profesionalisme dapat diartikan sikap dan prilaku auditor dalam menjalankan profesinya dengan kesungguhan dan tanggung jawab, serta memelihara citra publik (Antonius 2015). Auditor yang memiliki kemahiran profesionalisme yang baik, dapat dilihat dari tindakan apa yang akan dilakukan oleh auditor dalam melaksanakan pekerjaannya. Selain itu, auditor juga akan menggunakan fakta - fakta yang ada dengan cermat dan seksama dalam mengambil keputusan auditnya tanpa adanya pengaruh dari pihak lain.

Profesionalisme auditor dapat diartikan sikap dan prilaku dalam menjalankan profesinya dengan kesungguhan dan tanggung jawab, serta dalam melaksanakan pekerjaannya, auditor internal harus mengetahui tindakan apa yang harus dilakukan dan menggunakan fakta yang ada dalam mengambil keputusan tanpa dipengaruhi oleh kepentingan pihak lain. Berikut adalah pengukuran indikator profesionalisme auditor internal :
a. Pengabdian pada profesi
b. Kewajiban Sosial
c. Kemandirian
d. Keyakinan terhadap peraturan profesi
e. Hubungan dengan sesama profesi

\section{Pengalaman Kerja}

Pengalaman kerja adalah tingkat penguasaan pengetahuan serta keterampilan seseorang dalam pekerjaannya yang dapat diukur dari masa kerja dan dari tingkat pengetahuan serta keterampilan yang dimilikinya Antonius (2015). Menurut Arens (2004) sesuai dengan standar umum dalam Standar Profesional Akuntan Publik bahwa auditor disyaratkan memiliki pengalaman kerja yang cukup dalam profesi yang ditekuninya, serta dituntut untuk memenuhi kualifikasi teknis dan berpengalaman dalam bidang industri yang digeluti. Pengalaman dari seorang auditor harus diikuti pula dengan pendidikan formal yang dimilikinya.

Auditor internal yang berpengalaman, tentunya harus memiliki masa kerja yang banyak dan juga harus memiliki tingkat frekuensi pekerjaan yang tinggi pula dalam melaksanakan audit. Pengalaman kerja seseorang menunjukan jenis-jenis pekerjaan apa saja yang telah dilakukan seseorang dan akan memberikan peluang besar bagi seseorang untuk melakukan pekerjaan secara lebih baik. Adapun indikator yang dijadikan untuk pengkuruan pengalaman kerja antara lain :

a. Masa kerja seorang auditor (Hafizh, 2017)

b. Frekuensi pemeriksaan yang telah dilakukan (Aji, 2009)

c. Banyaknya pelatihan yang telah diikuti(Mansur, 2007)

\section{Penelitian yang Relevan}

Penelitian yang dilakukan oleh Putri (2015) yang berjudul Pengaruh Kompetensi dan Profesionalisme Auditor Internal terhadap Kualitas Audit (Studi Empiris pada BUMN dan BUMD di Kota Yogyakarta). Hasil penelitiannya mrenunjukan bahwa kompetensi dan profesionalisme berpengaruh positif dan signifikan terhadap kualitas audit internal.

Selanjutnya penelitian yang dilakukan oleh Peng Wi (2015) yang berjudul Pengaruh Independensi, Kompetensi, Etika, dan Pengalaman Kerja Terhadap Kualitas Audit pada Bank Konvensional. Hasil penelitian tersebut menunjukan bahwa Kompetensi dan Etika berpengaruh positif terhadap Kualitas Audit Internal, sedangkan Independnesi dan Penagalaman Kerja tidak berpengaruh terhadap kualitas Audit Internal pada Bank konvensional. 
Kemudian penelitian yang dilakukan oleh Otniel Lam Togar (2016) yaitu Pengaruh Kompetensi, Independensi, dan Motivasi terhadap Kualitas Audit Internal Studi Empiris pada Perbankan BUMN. Hasil penelitian menunjukan bahwa Kompetensi, Independensi, dan Motivas berpengaruh positif terhadap Kualitas Audit Internal.

\section{Pengaruh Kompetensi Auditor Terhadap Kualitas Audit Internal}

Kompetensi auditor adalah kualifikasi yang dibutuhkan oleh auditor untuk melaksanakan audit dengan benar (Antonius, 2015). Kompetensi yaitu suatu kemampuan yang dimiliki seorang auditor untuk dapat melaksanakan atau melakukan suatu pekerjaan berdasarkan atas keterampilan dan pengetahuan yang dimilikinya. Seorang auditor yang menjadi pihak independen harus memiliki pengetahuan yang baik agar dapat menerapkan pengetahuannya dalam menghasilkan kualitas audit yang baik.

Kompetensi dapat menetukan keberhasilan dalam pelaksanaan audit, tanpa kompetensi auditor internal pelaksanaan audit internal kurang berkualitas. Kualias audit dapat dicapai jika auditor memiliki kompetensi yang baik (Purwati, 2007). Semakin kompeten seorang auditor maka kualitas audit yang akan dihasilkan juga semakin baik. Berdasarkan penjelasan diatas, maka hipotesis pertama dirumuskan sebagai berikut:

H1: Kompetensi berpengaruh positif terhadap kualitas audit internal

\section{Pengaruh Profesionalisme Auditor Terhadap Kualitas Audit Internal}

Profesionalisme auditor internal adalah sikap auditor dalam melaksanakan proses audit internal yang mengacu pada standar audit yang berlaku dan bekerja sesuai dengan kemampuan, keahlian, dan pengetahuan yang dimiliki oleh auditor tersebut. Agar laporan audit yang dihasilkan berkualitas, maka auditor harus menjalakan pekerjaanya secara profesional (Robi, 2015).

Auditor internal dituntut secara profesional untuk melaksanakan fungsi audit dengan baik. Jadi seorang auditor dapat menghasilkan laporan audit yang berkualitas jika auditor tersebut melaksanakan pekerjaanya secara profesional. Hal ini menjelaskan jika semakin profesional seoranga auditor internal maka semakin baik kualitas audit yang dihasilkan. Berdasarkan uraian diatas, maka hipotesis kedua penelitian ini adalah :

H2: Profesionalisme berpengaruh positif terhadap kualitas audit internal

\section{Pengaruh Pengalaman Kerja Auditor Terhadap Kualitas Audit Internal.}

Pengalaman kerja adalah tingkat penguasaan pengetahuan serta keterampilan seseorang dalam pekerjaannya yang dapat diukur dari masa kerja dan dari tingkat pengetahuan serta keterampilan yang dimilikinya Antonius (2015). Semakin banyak lama masa kerja auditor, maka akan menghasilkan kualitas audit yang berkualitas. Hal ini dikarenakan pengalaman kerja tersebut membentuk seorang auditor yang ahli dalam mengaudit secara teknis maupun psikis (Ajeng, 2016).

Jika dilihat dari segi lamanya menjadi auditor, seorang auditor yang kurang berpengalaman akan lebih banyak melakukan kesalahan dalam melakukan pekerjaan dibandingkan dengan dengan auditor yang sudah berpengalaman, yang mana membuat auditor tersebut memiliki kemampuan untuk memperoleh informasi yang relevan, mendeteksi kesalahan, dan mencari penyebab munculnya masalah. Hal ini menjadikan bahwa semakin lama masa kerja dan pengalaman auditor maka akan semakin baik dan meningkatnya kualitas audit yang dihasilkan. Berdasarkan penjelasan diatas, maka hipotesis ketiga yaitu :

H3: Pengalaman kerja auditor berpengaruh positif terhadap kualitas audit internal 


\section{Kerangka Konseptual}

Dari penjelasan tersebut, maka secara sederhana kerangka konseptual penelitian ini dapat digambarkan sebagai berikut:

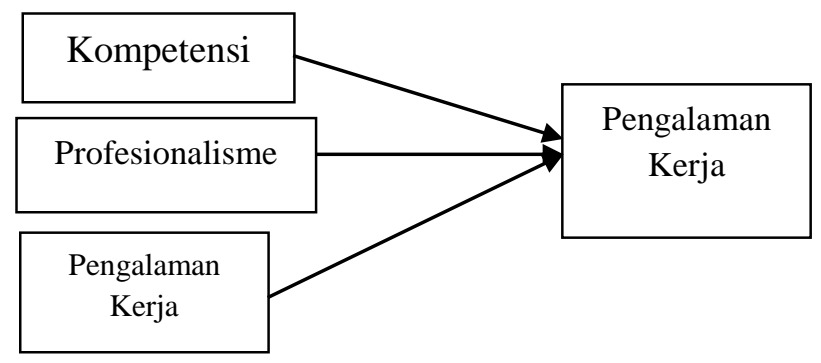

\section{METODE PENELITIAN}

\section{Jenis Penelitian}

Penelitian ini merupakan penelitian kausatif. Penelitian kausatif merupakan tipe penelitian dengan karakteristik masalah berupa sebab-akibat antara dua variabel atau lebih, yakni melihat pengaruh kompetensi, profesionalisme dan pengalaman kerja auditor terhadap kualitas audit internal pada Perusahaan Swasta dan BUMN.

\section{Populasi dan Sampel}

Populasi pada penelitian ini adalah Perusahaan Swasta dan BUMN di kota Padang yang memiliki beberapa auditor internal diperusahaannya. Sampel dalam penelitian ini adalah seluruh auditor internal di Perusahaan Swasta dan BUMN di kota Padang.

\section{Jenis dan Sumber Data}

Jenis data dalam penelitian ini adalah data subjek, yaitu data yang berupa opini, sikap, pengalaman, dan karakteristik dari seseorang atau sekelompok orang yang menjadi subjek penelitian ini. Sumber data dalam penelitian ini adalah data primer, yaitu data yang diperoleh langsung dari sampel yang telah ditentukan untuk diteliti atau melalui sumber asli atau tanpa melalui perantara, dengan menggunakan metode survey dengan menggunakan kuesioner.

\section{Teknik Pengumpulan Data}

Cara mengumpulkan data serta keterangan yang diperlukan dalam penyusunan penelitian ini, penulis menggunakan teknik pengumpulan data dengan kuesioner, yaitu pengumpulan data dengan cara membuat daftar pertanyaan yang diajukan kepada responden yang telah ditetapkan sebagai sampel.

\section{Variabel Penelitian}

Variabel terikat (Dependent Variable) dalam penelitian ini adalah kualitas audit internal (Y). Variabel bebas (Independent Variable) dalam penelitian ini adalah kompetensi kompetensi (X1), profesionalisme (X2), dan pengalaman kerja(X3).

\section{Instrumen Penelitian}

Penelitian ini diukur dengan menggunakan skala likert (5:4:3:2:1). Semua item pertanyaan diukur dengan skala likert 1-5, untuk mengukur sikap yang menyatakan setuju atau 
ketidaksetujuannya terhadap pertanyaan yang diajukan dengan skor 5 SS (sangat setuju), 4 S (setuju), 3 R (ragu-ragu), 2 TS (tidak setuju), dan 1 STS (sangat tidak setuju).

\section{Uji Instrumen}

\section{Uji Validitas}

Menurut Ghozali (2007:45), uji validitas dilakukan untuk mengetahui apakah alat ukur yang telah disusun benar-benar mengukur apa yang telah diukur. Uji validitas digunakan seberapa cermat suatu alat melakukan fungsi ukurannya.

\section{Uji Reabilitas}

Uji reliabilitas untuk mengetahui apakah alat pengumpul data pada dasarnya menunjukkan tingkat ketepatan, keakuratan, kestabilan atau konsistensi alat tersebut dalam mengungkapkan gejala tertentu dari sekelompok individu, walaupun dilakukan pada waktu yang berbeda. Uji kehandalan dilakukan terhadap pertanyaan-pertanyaan yang sudah valid.

\section{Uji Asumsi Klasik}

\section{Uji Normalitas}

Menurut Ghozali (2007:110), uji normalitas bertujuan untuk menguji apakah dalam model regresi variabel penggangu atau residual memiliki distribusi normal. Uji normalitas dilaksanakan dengan metode kolmogorov smirnov, dengan melihat nilai signifikansi pada 0,05. Jika nilai signifikansi yang dihasilkan >0,05 maka data berdistribusi normal.

\section{Uji Multikolonearitas}

Model regresi yang baik adalah tidak terjadinya korelasi diantara variabel bebas. Jika terjadi korelasi, maka dapat dikatakan bahwa variabel independen yang nilai korelasi antar sesama variabel sama dengan nol. Untuk mengujinya, dilakukan dengan melihat nilai Variance Inflantions Factor (VIF). Jika nilai VIF $<10$ dan tolerance $>0,1$, maka variabel dapat dikatakan bebas multikolonearitas

\section{Uji Heterokedastisitas}

Menurut Ghozali (2007:91), uji heterokedastisitas bertujuan untuk menguji apakah dalam model regresi terjadi ketidaksamaan varian dari residual satu pengamatan ke residual satu pengamatan yang lain. Jika residual satu pengamatan ke pengamatan lain tetap, maka disebut homokedastisitas dan jika berbeda maka disebut heterokedastisitas. Pengujian ini menggunakan uji Glejser. Apabila Sig > 0,05, maka tidak terdapat gejala heterokedastisitas. Model regresi yang baik adalah tidak terjadi heterokedastisitas.

\section{Teknik Analisis Data}

Data yang digunakan oleh peneliti akan dianalisis dengan teknik analisis sebagai berikut :

\section{Analisis Diskriptif}

Analisis deskriptif merupakan proses pengolahan data yang telah didapat dari responden. Data tersebut dianalisis dengan langkah - langkah melakukan verivikasi data, menghitung nilai jawaban responden, dan menghitung nilai Tingkat Capaian Responden (TCR). Nilai persentase dimasukkan ke dalam kriteria sebagai berikut: 
a. Interval jawaban responden $76-100 \%$ kategori jawaban baik.

b. Interval jawaban responden 56-75\% kategori jawaban cukup baik.

c. Interval jawaban responden $<56 \%$ kategori jawaban kurang baik.

\section{Analisis Kuantitatif}

Analisis kuantitatif adalah analisis yang berhubungan dengan perhitungan statistik yang dicari dengan program SPSS.

\section{Metode Analisi Data}

\section{a. Uji Regresi Berganda}

Dalam penelitian ini, hipotesis yang diajukan adalah membuktikan pengaruh variabel independen terhadap variabel dependen, maka teknik pengujian hipotesis dalam penelitian ini menggunakan metode analisis regresi berganda berikut ini :

$$
\mathrm{Y}=\alpha+\beta 1 \mathrm{X} 1+\beta 2 \mathrm{X} 2+\beta 3 \mathrm{X} 3+\mathrm{e}
$$

$$
\begin{aligned}
& \text { Keterangan : } \\
& Y=\text { Kualitas Audit Internal } \\
& X_{1}=\text { Kompetensi } \\
& X_{2}=\text { Profesionalisme } \\
& X_{3}=\text { Pengalaman Kerja } \\
& \beta_{1}=\text { Koefisien regresi } X_{1} \\
& \beta_{2}=\text { Koefisien regresi } X_{2} \\
& \beta_{3}=\text { Koefisien regresi } X_{3} \\
& \alpha=\text { Koefisien korelasi } \\
& e=\text { Error }
\end{aligned}
$$

\section{b. Uji Model}

\section{Uji F F-test}

Uji F dilakukan untuk menguji apakah secara serentak variabel independen mampu menjelaskan variabel dependen secara. Nilai sig 0,00 $<0,05$ menunjukkan bahwa variabel independen secara bersama - sama memberikan pengaruh yang signifikan terhadap variabel dependen.

\section{Uji Koefisisen Determinasi}

Menurut Ghozali (2007), koefisien determinasi $\left(\mathrm{R}^{2}\right)$ mengukur seberapa jauh kemampuan dalam menerangkan variabel dependen. Nilai koefisien determinasi adalah antara nol dan satu.Nilai $R^{2}$ yang kecil berarti kemampuan variabel independen dalam menjelaskan varian variabel dependen amat terbatas.Nilai yang mendekati satu berarti variabel independen memberikan hampir semua informasi yang dibutuhkan untuk memprediksi varian variabel dependen.

\section{Uji Hipotesis}

Pengujian ini dilakukan untuk menguji apakah secara terpisah variabel independen mampu menjelaskan variabel dependen secara baik.

a. Jika tingkat signifikan $<\alpha=0,05$ maka kepetusan dari hasil tersebut menerima hipotesis $\mathrm{H}_{1}$, $\mathrm{H}_{2}$, dan $\mathrm{H}_{3}$. 
b. Jika tingkat signifikan $>\alpha=0,05$ maka hipotesis $\mathrm{H}_{1}, \mathrm{H}_{2}$, dan $\mathrm{H}_{3}$ ditolak. Dengan tingkat kepercayaan untuk pengujian hipotesis adalah $95 \%$ atau $(\alpha)=0,05$.

\section{Definisi Operasional}

Agar tidak terjadi kesalahan dalam memahami dan mengartikan variabel - variabel yang digunakan dalam penelitian ini, maka berikut ini penjelasan dari pengertian variabel - variabel tersebut, yaitu :

a. Kualitas Audit Internal, yaitu seberapa baik sebuah pekerjaan diselesaikan dibandingakan dengan kriteria yang telah ditetapkan, dimana dalam melaksanakan tugasnya auditor tersebut berpedoman pada standar auditing.

b. Kompetensi Auditor Internal, yaitu kemampuan yang harus dimiliki oleh seorang auditor untuk dapat melakukanpekerjaannya dalam mengaudit dengan benar.

c. Profesionalisme Auditor Internal, yaitu sikap dan perilaku auditor dalam menjalankan profesinya dengan bersungguh-sungguh dan tanggung jawab, dan auditor harus melaksanakan pekerjaannya sesuai dengan fakta-fakta yang ada.

d. Pengalaman Kerja Auditor Internal, yaitu lamanya masa kerja seseorang dalam melaksanakan suatu jenis pekerjaan dimana seseorang yang memiliki pengalaman kerja yang lama maka hal ini akan meningkatkan pengetahuan dan keterampilan seseorang dalam bekerja.

\section{HASIL DAN PEMBAHASAN}

\section{Gambaran Umum Objek Penelitian}

Populasi dalam penelitian ini adalah Perusahaan Swasta dan BUMN di Kota Padang yang memiliki beberapa auditor internal diperusahaannya, yaitu sebanyak 8 banyak perusahaan. Sampel dalam penelitian ini adalah seluruh auditor internal di Perusahaan Swasta dan BUMN di Kota Padang.

\section{Demografi Responden}

Dari hasil penelitian yang telah dilakukan dapat dilihat karakteristik dari seluruh responden yang menjadi sampel dalam penelitian ini, antara lain adalah karakteristik responden berdasarkan jenis kelamin, umur, tingkat pendidikan, dan lama bekerja.

\section{Uji Asumsi Klasik} Uji Normalitas

Tabel 1

One-Sample Kolmogorov-Smirnov Test

\begin{tabular}{llr}
\hline & & $\begin{array}{c}\text { Unstandardized } \\
\text { Residual }\end{array}$ \\
\hline $\mathrm{N}$ & & 34 \\
\hline Normal Parameters & &, 0000000 \\
\cline { 2 - 3 } & Mean & 1,67936766 \\
\cline { 2 - 3 } Most Extreme Differences & Std. Deviation &, 070 \\
\cline { 2 - 3 } & Absolute &, 066 \\
\cline { 2 - 3 } & Positive &,- 070 \\
\cline { 2 - 3 } & Negative &, 070 \\
\hline Test Statistic & &, 200 \\
\hline Asymp. Sig. (2-tailed) & & \\
\hline
\end{tabular}


Uji normalitas dilaksanakan dengan metode kolmogorov smirnov, dengan melihat nilai signifikansi pada 0,05. Uji normalitas dapat dilihat pada tabel . Hasil dari uji normalitas yang dilakukan menghasilkan perhitungan Kolmogorov-Smirnov sebesar 0,070 dengan nilai signifikansi sebesar 0,200. Berdasarkan perhitungan diatas, nilai signifikansi 0,200>0,05, sehingga dapat dikatakan data yang digunakan dalam penelitian ini berdistribusi normal.

\section{Uji Multikolinearitas}

Uji multikolinearitas dapat dilihat pada tabel. Untuk mengujinya, dilakukan dengan melihat nilai Variance Inflantions Factor (VIF). Jika nilai VIF $<10$ dan tolerance $>0,1$, maka variabel dapat dikatakan bebas multikolonearitas. Hasilnya menunjukan bahwa nilai tolerance untuk variabel kompetensi sebesar 0,769, variabel profesionalisme sebesar 0,630 dan variabel pengalaman kerja sebesar 0,577. Sedangkan nilai VIF variabel kompetensi sebesar 1,300, variabel profesionalisme sebesar 1,587, dan variabel pengalaman kerja sebesar 1,734. Dari nilai tolerance dan VIF seluruh variabel tersebut, didapatkan bahwa seluruh variabel independen memiliki nilai tolerance $>0,10$ serta memiliki nilai VIF $<10$. Dengan demikian, dapat dikatakan bahwa tidak ditemukan korelasi variabel-variabel bebas antara satu dengan yang lainnya, atau dapat disimpulkan tidak terjadi multikolinearitas.

\section{Tabel 2}

\section{Uji multikolonieritas} Coefficients $^{\mathrm{a}}$

\begin{tabular}{|c|c|c|c|c|c|c|c|}
\hline \multirow[b]{2}{*}{ Model } & \multicolumn{2}{|c|}{$\begin{array}{l}\text { Unstandardized } \\
\text { Coefficients }\end{array}$} & \multirow{2}{*}{$\begin{array}{c}\text { Standardized } \\
\text { Coefficients }\end{array}$} & \multirow[b]{2}{*}{$\mathrm{t}$} & \multirow[b]{2}{*}{ Sig. } & \multicolumn{2}{|c|}{$\begin{array}{l}\text { Collinearity } \\
\text { Statistics }\end{array}$} \\
\hline & $\mathrm{B}$ & Std. Error & & & & Tolerance & VIF \\
\hline 1 (Constant) & 22,112 & 6,472 & & 3,417 & ,002 & & \\
\hline Kompetensi & ,277 & , 183 & 217 & 1,514 & ,140 & ,769 & 1,300 \\
\hline Profesionalisme & , 151 & , 116 & ,206 & 1,300 & 204 & 630 & 1,587 \\
\hline $\begin{array}{l}\text { Pengalaman } \\
\text { Kerja }\end{array}$ & ,472 & ,175 & , 448 & 2,704 & ,011 & ,577 & 1,734 \\
\hline
\end{tabular}

\section{Uji Heterokedastisitas}

Tabel 3

\section{Uji Heterokedastisitas} Coefficients $^{\mathrm{a}}$

\begin{tabular}{|c|c|c|c|c|c|}
\hline \multirow[b]{2}{*}{ Model } & Unstandardize & Coefficients & $\begin{array}{c}\text { Standardized } \\
\text { Coefficients }\end{array}$ & & \\
\hline & B & Std. Error & Beta & $\mathrm{t}$ & Sig. \\
\hline (Constant) & $-2,357$ & 3,817 & &,- 618 &, 541 \\
\hline Kompetensi & 086 & ,108 & 157 &, 795 & ,433 \\
\hline Profesionalisme &,- 109 & ,068 &,- 348 & $-1,598$ & ,121 \\
\hline Pengalaman Kerja &, 115 &, 103 & 254 & 1,115 & 274 \\
\hline
\end{tabular}

Hasil uji heterokedastisitas dapat dilihat pada tabel. Berdasarkan hasil uji heterokedastisitas yang terdapat pada tabel diatas, didapatkan nilai signifikansi dari variabel kompetensi sebesar 0,433, nilai signifikansi variabel profesionalisme sebesar 0,121 , dan nilai 
signifikansi untuk variabel pengalaman kerja sebesar 0,274. Dari hasil tersebut, diketahui bahwa seluruh variabel dalam penelitian ini memiliki nilai signifikansi $>0,05$, yang berarti dalam model regresi ini dapat dikatakan bahwa tidak ada variabel yang signifikan dengan variabel absut. Dengan demikian dapat disimpulkan model yang digunakan dalam penelitian ini terbebas dari heterokedastisitas.

\section{Model Regresi Berganda}

Berdasarkan pengolahan data statistik tabel maka diperoleh persamaan regresi linear sebagai berikut :

$$
\mathrm{Y}=22,112+0,277 \mathrm{X} 1+0,151 \mathrm{X} 2+0,472 \mathrm{X} 3+\mathrm{e}
$$

$$
\begin{aligned}
& \text { Keterangan : } \\
& Y=\text { Kualitas Audit Internal } \\
& X_{1}=\text { Kompetensi } \\
& X_{2}=\text { Profesionalisme } \\
& X_{3}=\text { Pengalaman Kerja } \\
& \beta_{1}=\text { Koefisien regresi } X_{1} \\
& \beta_{2}=\text { Koefisien regresi } X_{2} \\
& \beta_{3}=\text { Koefisien regresi } X_{3} \\
& \alpha=\text { Koefisien korelasi } \\
& e=\text { Error }
\end{aligned}
$$

\begin{tabular}{|c|c|c|c|c|c|}
\hline \multirow[b]{2}{*}{ Model } & Unstandardize & Coefficients & $\begin{array}{c}\text { Standardized } \\
\text { Coefficients }\end{array}$ & \multirow[b]{2}{*}{$\mathrm{t}$} & \multirow[b]{2}{*}{ Sig. } \\
\hline & B & Std. Error & Beta & & \\
\hline 1 (Constant) & 22,112 & 6,472 & & 3,417 &, 002 \\
\hline Kompetensi & ,277 &, 183 & ,217 & 1,514 &, 140 \\
\hline Profesionalisme &, 151 & ,116 & ,206 & 1,300 & ,204 \\
\hline Pengalaman Kerja &, 472 &, 175 & ,448 & 2,704 & 011 \\
\hline
\end{tabular}

\section{Tabel 4}

Model Regresi Berganda

Coefficients $^{\mathbf{a}}$

a. Dependent Variable: Kualitas Audit internal

Angka yang dihasilkan dalam persamaan regresi berganda tersebut dapat dijelaskan sebagai berikut :

\section{Konstanta $(\alpha)$}

Nilai konstanta sebesar 22,112 yang berarti bahwa jika variabel independen yaitu kompetensi, profesionalisme dan pengalaman kerja auditor adalah 0,maka nilai kualitas audit internal berada pada 22,112 satuan.

\section{Koefisien Regresi $\beta_{1} X_{1}$}

Koefisien kompetensi auditor sebesar 0,277 yang mengindikasikan bahwa setiap peningkatan kompetensi auditor satu satuan akan mengakibatkan peningkatan kualitas audit internal sebesar 0,277 satuan. Nilai koefisien $\beta$ dari variabel $\mathrm{X}_{1}$ bernilai positif yaitu 0,277.

3. Koefisien Regresi $\boldsymbol{\beta}_{2} \mathrm{X}_{2}$

Koefisien profesionalisme auditor sebesar 0,151 yang mengindikasikan bahwa setiap peningkatan profesionalisme auditor satu satuan akan mengakibatkan peningkatan kualitas 
audit internal sebesar 0,151 satuan. Nilai koefisien $\beta$ dari variabel $\mathrm{X}_{2}$ bernilai positif yaitu 0,151 .

\section{Koefisien Regresi $\beta_{3} \mathrm{X}_{3}$}

Koefisien pengalaman kerja auditor sebesar 0,472 mengindikasikan bahwa setiap peningkatan pengalaman kerja auditor satu satuan akan mengakibatkan peningkatan kualitas audit internal sebesar 0.472 satuan. Nilai koefisien $\beta$ dari variabel $\mathrm{X}_{3}$ bernilai positif, yaitu 0,472 .

\section{Uji Model}

\section{Uji Koefisien Determinasi}

Koefisien determinasi dapat dilihat pada tabel. nilai Adjust $R$ Square adalah sebesar 0,477 atau sama dengan 47,7\%. Hal ini menjelaskan bahwa variabel kompetensi, profesionalisme, dan pengalaman kerja auditor memiliki kontribusi dalam menerangkan variabel dependen yaitu sebesar $47,7 \%$. Sedangkan sisanya yaitu sebesar 52,3\% dipengaruhi oleh variabel lain yang tidak terdeteksi dalam penelitian ini.

\section{Tabel 5}

\section{Koefisien Determinasi} Model Summary ${ }^{b}$

\begin{tabular}{|c|c|c|c|c|}
\hline Model & $\mathrm{R}$ & R Square & Adjusted R Square & $\begin{array}{l}\text { Std. Error of the } \\
\text { Estimate }\end{array}$ \\
\hline 1 &, $724^{\mathrm{a}}$ &, 525 & ,477 & 1,761 \\
\hline
\end{tabular}

\section{Uji F (F-test)}

\section{Tabel 6 \\ Uji F \\ ANOVA}

\begin{tabular}{|c|c|c|c|c|c|}
\hline Model & $\begin{array}{l}\text { Sum of } \\
\text { Squares }\end{array}$ & $\mathrm{df}$ & Mean Square & $\mathrm{F}$ & Sig. \\
\hline 1 Regression & 102,813 & 3 & 34,271 & 11,047 &, $000^{\mathrm{b}}$ \\
\hline Residual & 93,069 & 30 & 3,102 & & \\
\hline Total & 195,882 & 33 & & & \\
\hline
\end{tabular}

a. Dependent Variable: Kualitas Audit Internal

b. Predictors: (Constant), Pengalaman Kerja, Kompetensi, Profesionalisme

Uji F dibuktikan dengan hasil perhitungan pada table 6.Berdasarkan pengolahan data menunjukkan nilai $F_{h i t u n g}$ sebesar 11,047 dan signifikan pada nilai signifikan 0,000. Nilai $F_{\text {hitung }}>$

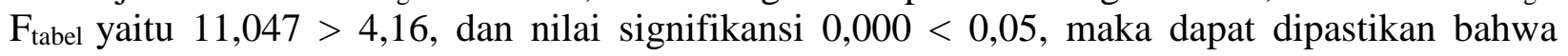
model regresi dalam penelitian ini dapat digunakan dalam memprediksi pengaruh variabel independen terhadap variabel dependen dalam penelitian ini. Dengan demikian, dapat disimpulkan bahwa kompetensi, profesionalisme, dan pengalaman kerja auditor secara bersamasama atau secara simultan berpengaruh signifikan terhadap kualitas audit internal.

\section{Uji Hipotesis (t-test)}

Berdasarkan hasil dari tabel 4, dapat diketahui bahwa koefisien $\beta$ Kompetensi bernilai positif sebesar 0,277 dan nilai $t$ hitung 1,514 dengan nilai signifikansi 0,140 >0,05. Hal ini berarti bahwa Kompetensi berpengaruh positif dan tidak signifikan terhadap Kualitas Audit Internal, sehingga 
dapat di simpulkan bahwa hipotesi 1 ditolak. Berdasarkan hasil dari tabel 4, dapat diketahui bahwa koefisien $\beta$ Profesionalisme bernilai positif sebesar 0,151 dan nilai $t$ hitung 1,300 dengan nilai signifikan 0,204 >0,05. Hal ini berarti bahwa Profesionalisme berpengaruh positif dan tidak signifikan terhadap Kualitas Audit Internal, sehingga dapat di simpulkan bahwa hipotesis 2 ditolak. Berdasarkan hasil dari tabel 4 , dapat diketahui bahwa koefisien $\beta$ Pengalaman Kerja bernilai positif sebesar 0,472 dan nilai $t$ hitung 2,704 dengan nilai signifikan $0,011<0,05$. Hal ini berarti bahwa Pengalaman Kerja berpengaruh positif dan signifikan terhadap Kualitas Audit Internal, sehingga dapat di simpulkan bahwa hipotesis 3 diterima.

\section{PEMBAHASAN}

\section{Pengaruh Kompetensi Auditor Terhadap Kualitas Audit Internal}

Berdasarkan hasil uji hipotesis pertama, ditemukan dalam penelitian ini bahwa hipotesis $\mathrm{H} 1$ ditolak sehingga dapat disimpulkan bahwa kompetensi auditor berpengaruh positif dan tidak signifikan terhadap kualitas audit internal. Hasil penelitian ini tidak sejalan dengan penelitian yang dilakukan oleh Putri (2015) yang menunjukan bahwa kompetensi auditor internal berpengaruh terhadap kualitas audit internal. Namun hasil penelitian ini sejalan dengan penelitian yang dilakukan Elen (2013) yang menjelaskan bahwa kompetensi tidak berpengaruh terhadap kualitas audit internal. Tidak berpengaruhnya variabel kompetensi dikarenakan seringkali pengetahuan yang dimiliki dianggap dapat meningkatkan kompetensi auditor yang dilihat dari latar belakang pendidikan formal akuntansi.

Namun hal ini dapat dilihat bahwa kompetensi yang baik dari segi pendidikan dan pengetahuan belum tentu mencerminkan kemampuan sesungguhnya saat berhadapan didunia praktek (Trimanto, 2011).Selain itu auditor yang mempunyai pengetahuannya yang rendah belum mampu melakukan analisis yang lebih teliti dan rinci dalam melakukan audit, sehingga hal juga ini tidak memberikan pengaruh terhadap kualitas audit internal yang dihasilkan. Hal ini menggambarkan bahwa kompetensi yang memiliki pengetahuan formal atau non formal, kemampuan dan orientasi profesi bukanlah hal yang mempengaruhi kualitas audit (Elen, 2013).

\section{Pengaruh Profesionalisme Auditor Terhadap Kualitas Audit Internal}

Berdasarkan hasil uji hipotesis kedua, ditemukan dalam penelitian ini bahwa hipotesis $\mathrm{H} 2$ ditolak sehingga dapat disimpulkan bahwa profesionalisme tidak berpengaruh signifikan terhadap kualitas audit internal. Hasil penelitian ini sejalan dengan penelitian yang dilakukan oleh (Suardinatha, 2016) yang menjelaskan bahwa profesionalisme tidak berpengaruh terhadap kualitas audit.

Dalam hal ini seorang auditor dituntut agar bertindak profesional dalam melakukan pemeriksaan. Auditor yang memiliki profesionalisme yang rendah tidak berpengaruh terhadap kualitas audit yang dihasilkan, oleh sebab itu profesionalisme perlu ditingkatkan, karena sangat penting dalam melakukan pemeriksaan sehingga akan memberikan pengaruh pada kualitas auditnya. Tidak berpengaruhnya profesionalisme terhadap kualitas audit internal dikarenakan sebagian besar dalam penelitian ini memang masih terdapat auditor yang masa kerjanya dalam kategori kurang dari 3 tahun dan bahkan ada juga kurang dari 1 tahun, sehingga responden belum mempunyai pandangan profesionalisme yang tinggi dalam melakukan tugasnya.

\section{Pengaruh Pengalaman Kerja Auditor Terhadap Kualitas Audit Internal}

Berdasarkan hasil uji hipotesis ketiga, ditemukan bahwa dalam penelitian ini bahwa hipotesis $\mathrm{H} 3$ diterima sehingga dapat disimpulkan bahwa pengalaman kerja berpengaruh positif dan signifikan 
terhadap kualitas audit internal. Artinya semakin lama seorang auditor berkerja maka semakin baik kualitas audit yang dihasilkan.

Hasil penelitian ini sejalan dengan penelitian yang dilakukan Ahmad (2016) yang menjelaskan bahwa secara parsial pengalaman kerja berpengaruh terhadap kualitas audit internal. Jika seorang auditor yang kurang berpengalaman akan lebih banyak melakukan kesalahan dalam melakukan pekerjaan dibandingkan dengan dengan auditor yang sudah berpengalaman yang mana membuat auditor tersebut memiliki kemampuan untuk memperoleh informasi yang relevan. Semakin tinggi pengalaman auditor, maka semakin mampu dan mahir auditor menguasai tugasnya sendiri maupun aktifitas yang di auditnya, Hal ini dikarenakan pengalaman kerja tersebut membentuk seorang auditor yang ahli dalam mengaudit secara teknis maupun psikis (Ajeng, 2016). Hal ini menjadikan bahwa semakin lama masa kerja dan pengalaman auditor maka akan semakin baik dan meningkatnya kualitas audit yang dihasilkan.

\section{KESIMPULAN DAN SARAN \\ Kesimpulan}

Berdasarkan hasil analisis data dan pengujian hipotesis yang telah dilakukan, maka dapat ditarik kesimpulan sebagai berikut :

1. Kompetensi auditor tidak berpengaruh signifikan terhadap kualitas audit internal pada perusahaan swasta dan BUMN.

2. Profesionalisme auditor tidak berpengaruh signifikan terhadap kualitas audit internal pada perusahaan swasta dan BUMN.

3. Pengalaman kerja auditor berpengaruh signifikan positif terhadap kualitas audit internal pada perusahaan swasta dan BUMN.

\section{Keterbatasan}

Meskipun peneliti telah berusaha merancang dan mengembangkan penelitian sedemikian rupa, namun masih terdapat beberapa keterbatasan dalam penelitian ini yang masih perlu revisi penelitian selanjutnya, antara lain:

1. Penelitian ini menggunakan metode pengumpulan data melalui kusioner sehingga data yang diperoleh berdasarkan persepsi responden saja, dan penelitian ini hanya dilakukan di perusahaan Swasta dan BUMN di Kota Padang

2. Dari hasil uji koefisien determinasi atau adjusted $R$-Square menjelaskan bahwa variabel kompetensi, profesionalisme, dan pengalaman kerja auditor memiliki kontribusi dalam menerangkan variabel dependen yaitu sebesar 47,7\%, sehingga masih ada variabel-variabel lain yang juga mempengaruhi.

\section{Saran}

Berdasarkan analisis data dan hasil yang diperoleh dalam penelitian ini, terdapat beberapa saran yang dapat dipertimbangkan antara lain :

1. Untuk penelitian selanjutnya yang juga menganalisa tentang kualitas audit internal ini, sebaiknya dapat mengembangkan variabel independen yang ada. Variabel - variabel yang sebaiknya dikembangkan dan dapat diteliti pada penelitian selanjutnya adalah seperti independensi, motivasi, etika auditor, akuntabilitas auditor, dan sebagainya.

2. Untuk metode pengumpulan data dalam penelitian selanjutnya sebaiknya menambah jumlah respondennya untuk memperkuat hasil penelitian yang diperoleh. 


\section{DAFTAR PUSTAKA}

Agoes, S. (2009). Auditing Jilid II (Pemeriksaan Akuntan) oleh Kantor Akuntan Publik. Edisi Ketiga. Jakarta: Penerbit Fakultas Ekonomi Universitas Indonesia

Agustin, R. dan Natasha, P. P. (2013). Pengaruh Kompetensi, Independensi, dan Profesionalisme terhadap Kualitas Audit (Studi Empiris pada Kantor Akuntan Publik Se Sumatra). Jurnal Ekonomi, 21(23)

Ahmad, A. R. (2016). Analisis Pengaruh Kompetensi, Pengalaman Kerja, IndependENSI, dan Motivasi terhadap Kualitas Audit pada Bank Syariah di Indonesia. Artikel Penelitian.

Ajeng, C. P. (2016). Pengaruh Pengalaman Kerja, Kompetensi, dan Independensi terhadap Kualitas Audit dengan Etika Auditor sebgai Variabel Moderasi. Artkel Penelitian. Fakultas Ekonomi Universitas Negri Yogyakarta.

Aminati, D. (2014). Pengaruh Profesionalisme Auditor terhadap Kualitas Kinerja Auditor Internal. Tesis. STIESIA Surabaya.

Arens et al. (2008). Auditing and Assurance Services- An Integrated Approach. Edisi Ke Duabelas. Pretince Hall.

Ariany, V. (2017). Pengaruh Independensi, dan Kompetensi Auditor terhadap Kualitas Audit Internal pada Bank BUMN di Medan. Riset dan Jurnal Akuntansi, 1(1)

Ayuningtyas, H. Y. (2012). Pengaruh Pengalaman Kerja, Independensi, Objektivitas, Integritas, dan Kompetensi Terhadap Kualitas Hasil Audit (Studi Kasus Pada Auditor Inspektorat Kota/Kabupaten di Jawa Tengah). Skripsi. Universitas Diponegoro.

Christiawan, Y. J. (2002). Kompetensi dan Independensi Akuntan Publik" : Refleksi Penelitian Empiris. Jurnal Akuntansi dan Keuangan, 4(2).

De Anglo, L.e. (1981). Auditor Size and Audit Quality. Journal Of Accounting and Economic.

Futri, P. S., \& Juliarsa, G. (2014). Pengaruh Independensi, Profesionalisme, Tingkat Pendidikan, Etika Profesi, Pengalaman dan Kepuasan Kerja Auditor Pada Kualitas Audit Kantor Akuntan Publik di Bali.

Ghozali. (2003). Analisi Multivariat Lanjutan dengan Program SPSS. Semarang. Badan Penerbit Universitas Diponegoro.

Institut Akuntan Publik Indonesia. (2001). Standar Profesional Akuntan Publik. Jakarta: Salemba Empat

Korsosium Organisasi Profesi Audit Internal. (2004). Standar Profesi Audit Internal. Jakarta: Yayasan Pendidikan Internal Audit.

Maulana, R. (2015). Pengaruh Kompetensi, Independensi, dan Profesiuonalisme terhadap Kualitas Audit Internal pada Bank Perkreditan Rakyat di Kabupaten Majalengka. Jurnal Ilmiah Manajemen dan Akuntansi, 2(2)

Nugraihi, P. (2015). Pengaruh Kompetensi dan Profresionalisme Auditor Internal terhadap Kualitas Audit. Artikel Penelitian. UNY.

Otniel La, T. (2016). Pengaruh Kompetensi, Independensi, dan Motivasi terhadap Kualitas Audit Internal. Artikel Penelitian. STIE Indonesia Banking School.

Peng wi. (2015). Pengaruh Independensi, Kompetensi Etika, dan Pengalaman Kerja Terhadap Kualitas Auditrto Internal pada Bank Konvesional. Artikel Penelitian. Universitas Budi Luhur Tanggerang.

Rosnidah, I. (2012). Model Pengukuran Kualitas Audit Internal. Jurnal Ekonomi dan Keuangan.

Samsi, N., dkk. (2013). Pengaruh Pengalaman Kerja, Independensi, dan Kompetensi terhadap Kualitas Audit: Etika Auditor sebagai Pemoderasi. Jurnal Ilmu dan Riset Akuntansi 
Sawyer, L. B., Dittenhoffer, M. A. Dan Scheiner, J. H. (2005). Sawyer's Internal Auditing. Audit Internal Sawyer. Edisi 5. Jakarta: Salemba Empat.

Suardinatha, M. H. dan Wirakusuma, M. G. (2016). Pengaruh Independensi Dan Profesionalisme Terhadap Kualitas Audit Dengan Kepuasan Kerja Sebagai Variabel Pemoderasi. E-Jurnal kuntansi Universitas Udayana: 2302-8558

Trimanto, dkk. (2011). Pengaruh Kompetensi dan Independensi auditor terhadap kualitas audit. Universitas Kristen Maranatha. 